Sains Malaysiana 50(10)(2021): 3035-3043

http://doi.org/10.17576/jsm-2021-5010-16

\title{
Dengue Virus Non-structural (NS) 1 Gene as A Molecular Marker for Early Detection of in vitro Dengue Virus Infection
}

(Gen Virus Denggi Bukan Struktur (NS) 1 sebagai Penanda Molekul untuk Pengesanan Awal Jangkitan Virus Denggi secara in vitro)

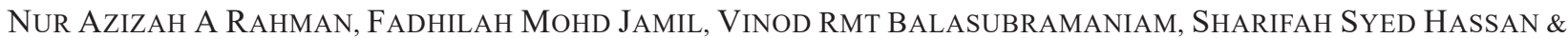
WEI BOON YAP*

\section{ABSTRACT}

Serology-based dengue assays at times produce inaccurate results especially in the early phase of disease onset. A more precise diagnostic approach detecting dengue infections in the early phase enables better management of the disease. This helps reduce dengue-associated morbidity and mortality. Besides, an early diagnosis of dengue is also very beneficial in a dengue outbreak and in endemic regions. In this light, this study aimed to determine the potential of the dengue virus (DENV) non-structural 1 (NS1) gene as an early detection biomarker. The cytopathic effects (CPE) were monitored and the cell death of DENV serotype-2 (DENV2)-infected Vero cells was evaluated for fourteen consecutive days. Only Lemos and in-house NS1-specific primer pairs showed positive amplifications in the preliminary primer validation. Thus, both of the primer pairs were then used to amplify the NS1 gene from the infected cells. The NS1 gene was detected as early as day-2 post-infection using the in-house primers. There was no amplicon produced using the Lemos primers. This is speculated to be attributable to the relatively lower complementarity of the primer sequences with that of the template and low amount of viral mRNA in the DENV2-infected cells. Conclusively, the DENV NS1 gene is a potential early detection marker, however, the NS1-specific primers should be pre-validated to ensure a reliable dengue diagnosis.

Keywords: Dengue; dengue virus (DENV); early diagnosis; non-structural (NS)1; polymerase chain reaction (PCR)

\section{ABSTRAK}

Ujian denggi berdasarkan serologi kadang-kadang memberikan hasil yang tidak tepat terutama pada fasa awal permulaan penyakit. Pendekatan diagnostik yang lebih tepat untuk mengesan jangkitan denggi pada fasa awal membolehkan pengurusan penyakit ini dengan lebih baik. Ini membantu mengurangkan morbiditi dan kematian yang berkaitan dengan denggi. Selain itu, diagnosis denggi awal juga sangat bermanfaat dalam wabak denggi dan di daerah endemik. Kajian ini bertujuan untuk menentukan potensi gen bukan struktur 1 (NS1) virus denggi sebagai biopenanda pengesanan awal. Kesan sitopatik (CPE) dipantau dan kematian sel Vero yang dijangkiti serotip-2 (DENV2) dinilai selama empat belas hari berturut-turut. Hanya pasangan primer khusus Lemos dan NS1 dalaman yang menunjukkan peningkatan positif dalam pengesahan primer awal. Oleh itu, kedua-dua pasangan primer kemudian digunakan untuk memperkuat gen NS1 daripada sel yang dijangkiti. Gen NS1 dikesan pada awal hari ke-2 selepas jangkitan menggunakan primer dalaman. Tidak ada amplikon yang dihasilkan menggunakan primer Lemos. Ini diduga disebabkan oleh pelengkap urutan primer yang lebih rendah dengan templat dan jumlah mRNA virus yang rendah pada sel yang dijangkiti DENV2. Kesimpulannya, gen DENV NS1 adalah penanda pengesanan awal yang berpotensi, namun, primer khusus NS1 harus disahkan terlebih dahulu untuk memastikan diagnosis denggi yang boleh dipercayai.

Kata kunci: Bukan struktur (NS)1; diagnosis awal; denggi; tindak balas rantai polimerase (PCR); virus denggi (DENV)

\section{INTRODUCTION}

Dengue has been recognized as a global public health issue and an endemic disease in most of the tropical and sub-tropical countries. In addition, it has also become a re-emerging viral disease due to global traveling and trading, and climate change (Ahmad et al. 2018). This disease is caused by a member virus of Flaviviridae, namely dengue virus (DENV) (Chambers et al. 1990). DENV is categorized into four antigenically different serotypes known as DENV1, DENV2, DENV3, and DENV4. 
Generally, recovery from an infection by a certain serotype does not provide lifelong immunity against the other dengue serotypes (Riverts et al. 2009; Tomlinson et al. 2009). Before 1970, there were only 9 countries badly affected by severe dengue epidemics. Currently, the viral disease has spread widely and is now recognized as an endemic in more than 100 countries throughout Africa, America, Eastern Mediterranean, South-East Asia and the Western Pacific. The America, South-East Asia and Western Pacific are among the most seriously affected regions. Likewise, in Malaysia, dengue cases have been on a steep rise since 1990 to 2013 and the accumulated number of dengue cases in 2014-2017 reached 414,740 (Hii et al. 2016; Packierisamy et al. 2015).

Dengue symptoms may vary from asymptomatic, undifferentiated to more severe forms and even death if left untreated (Bhatt et al. 2013). Therefore, it is critical to provide reliable diagnosis especially in the early stage in order to prevent adverse disease progression. Infected humans are DENV carriers who serve as a source for the virus transmission through mosquito vectors. Although anti-dengue agents and vaccines are thought to potentially prevent and control dengue infections in humans (Jasamai et al. 2019), up to date, none is available for clinical use to prevent and curb the disease (Guy et al. 2015; Pilay et al. 2017). The dengue treatment is purely based on supportive disease managements (Darwish et al. 2015).

Considering the unspecific clinical presentations of dengue, the unavailability of specific anti-dengue vaccines and drugs just yet, the laboratory confirmation especially at the early stage of dengue is essential. Detecting dengue rapidly in the early disease onset is imperative in reducing the disease mortality and morbidity, and medical burdens (Muller \& Young 2013; Tuiskunen Bäck \& Lundkvist 2013). There are several major diagnostic methods currently available for detecting dengue infections, ranging from various conventional diagnostics involving virus cultivation in cell culture, serological approaches detecting denguespecific antibodies to the viral RNA detection using molecular techniques, and more recently, biosensors (Alm et al. 2014; Darwish et al. 2015). However, according to Darwish et al. (2015), although the viral RNA detection using real-time polymerase chain reaction (RT-PCR) is relatively more sensitive, it is very costly and requires highly trained personnel to perform the test. Virus cultivation using cell culture, on the other hand, is rather laborious and also requires specifically trained personnel and high-level biosafety facilities to handle the diagnosis, not to mention the relatively long duration required for cytopathic effects (CPE) to appear.
These days, the routine laboratory diagnosis of dengue still relies heavily on serological approaches. In dengue serological tests, the specificity of antibodies targeting DENV poses a major concern. For example, IgMbased diagnosis may produce false-negative results in patients previously infected with DENV. This is because the titer of DENV-specific IgM is purportedly much lower in many secondary dengue infections (Guzman et al. 2010). The false-negative results may also occur in immunoglobulin-defective patients due to mutations in several genes responsible for the B cell differentiation (Ballow 2002). In addition, the cross-reactivity of the other flaviviral antigens such as Japanese encephalitis virus (JEV), yellow fever virus (YFV) and West Nile virus (WNV) with DENV-specific antibodies is also interfering with the diagnosis outcomes (Guzman et al. 2010). Plus, the detection of dengue-specific antibodies normally is not consistent in the early course of DENV infection. This is because the immune system requires a relatively longer duration following a virus infection to produce detectable antibody levels (Muller \& Young 2013). In light of the shortcomings of the currently employed dengue diagnostic methods, recently, a simpler polymerase-chain reaction (PCR)-based diagnosis has been proposed for the early detection of dengue (Alm et al. 2014; Darwish et al. 2015). An early diagnosis of dengue enables early medical interventions for dengue especially in endemic areas even before serious symptoms arise (Muller \& Young 2013).

The DENV non-structural 1 (NS1) gene has been one of the genes of interest in many PCR-based diagnoses. This is mainly attributable to the abundant expression and secretion of the NS1 gene product by infected cells even earlier than the onset of disease symptoms and antibody response (Muller \& Young 2013). On this account, this study aimed to investigate the potential of the DENV NS1 gene as an early molecular detection marker in vitro. The findings suggest the great potential of DENV NS1 gene as a reliable biomarker for early detection of dengue, provided the NS1-specific primer sequences are matched preliminarily with the NSI gene of the circulating or target dengue serotypes.

\section{MATERIALS AND METHODS}

\section{CELL CULTIVATION}

The African green monkey kidney (Vero) cell line (ATCC CCL81 $\left.{ }^{\mathrm{TM}}\right)$ was cultured in Roswell Park Memorial Institute (RPMI) supplemented with 10\% (v/v) fetal bovine serum (FBS) and 1\% penicillin-streptomycin (PenStrep) (RPMI/FBS/PenStrep) at $37{ }^{\circ} \mathrm{C}, 5 \% \mathrm{CO}_{2}$ (Esco Global, USA) until Vero cells were $80 \%$ confluent. 


\section{PROPAGATION OF DENV2}

Vero cells were rinsed twice with $5 \mathrm{~mL} 1 \mathrm{X}$ phosphate buffered saline (PBS). The fresh RPMI/FBS/PenStrep was then added into the flask prior to virus infection. About $1 \mathrm{~mL}$ of DENV2 stock was added into the flask and incubated at $37{ }^{\circ} \mathrm{C}, 5 \% \mathrm{CO}_{2}$ for 5 days. CPE were monitored daily. The infected cells and medium were harvested and stored at $-80{ }^{\circ} \mathrm{C}$ (ThermoFisher Scientific, USA) until further use.

\section{DETERMINATION OF 50\% TISSUE CULTURE INFECTIOUS DOSE $\left(\right.$ TCID $\left._{50}\right)$ OF DENV2}

$\mathrm{TCID}_{50}$ was performed to determine the titer of DENV2. Ten-fold serially diluted DENV2 solutions $\left(10^{-2}-10^{-20}\right)$ were prepared using FBS-free RPMI medium. The virus infection was carried out in quadruplicate on 12-well plates. Vero cells $\left(1 \times 10^{4}\right.$ cells $\left./ \mathrm{mL}\right)$ were seeded and incubated at $37{ }^{\circ} \mathrm{C}, 5 \% \mathrm{CO}_{2}$ until $80 \%$ confluent. The cells were rinsed with fresh media, $2 \mathrm{~mL}$ of each virus dilution was added into each well. The virus adsorption was performed for 1 hour at $37{ }^{\circ} \mathrm{C}$. The plates were swirled gently every $15 \mathrm{~min}$ during incubation. After incubation, the media was discarded and replaced with fresh RPMI/FBS/PenStrep. The plates were incubated at $37{ }^{\circ} \mathrm{C}, 5 \% \mathrm{CO}_{2}$ for 5 days. $\mathrm{CPE}$ were monitored and recorded to determine the $\mathrm{TCID}_{50}$ and multiplicity of infection (MOI).

$\mathrm{MOI}=[$ plaque forming unit $(\mathrm{PFU})$ of virus $/ \mathrm{mL}] /$ number of viable cells

$$
\mathrm{PFU} / \mathrm{mL}=0.7 \times \mathrm{TCID}_{50}
$$

\section{VIABILITY OF DENV2-INFECTED VERO CELLS}

Vero cells were infected with $2 \mathrm{~mL}$ of pre-warmed virus solution at MOI of 0.5 . Uninfected cells were prepared and used as control in the experiment. DENV2-infected cells were harvested on day-1 to -14 post-infection (p.i). About $10 \mu \mathrm{L}$ of cell suspension was mixed with $10 \mu \mathrm{L}$ of $0.4 \%(\mathrm{w} / \mathrm{v})$ trypan blue staining solution. The mixture was transferred onto a hemocytometer and covered with a cover slip. The numbers of living and dead cells were enumerated under an inverted light microscope at $4 \times$ magnification. The percentage of cell death was determined as described previously (Tan et al. 2016).

$$
\text { Cell death }(\%)=\frac{\text { Number of dead cells }}{\text { Total number of cells }} \times 100 \%
$$

TOTAL RNA ISOLATION AND FIRST-STRAND CDNA SYNTHESIS

The total RNA was extracted from DENV2-infected cells using Trizol LS solution as described (Tan et al. 2016; Yap et al. 2020). The total RNA was converted into the firststrand complementary DNA (cDNA) by using Moloney Murine Leukemia Virus Reverse Transcriptase (M-MLV RT) (Promega; Madison, Wisconsin, USA). Briefly, 25 $\mu \mathrm{L}$ of reverse transcription mixture was prepared as follows: $0.5 \mu \mathrm{g}$ total RNA, $0.5 \mu \mathrm{g}$ oligo-dT universal primer (Promega; Madison, Wisconsin, USA), 1X M-MLV buffer, 200 U M-MLV RT and 1.25 mM dNTPs (Promega; Madison, Wisconsin, USA). The reverse transcription was carried out at $37^{\circ} \mathrm{C}$ for $1 \mathrm{~h}$. The synthesized first-strand cDNA was stored at $-20^{\circ} \mathrm{C}$ until further use.

\section{SELECTION AND DESIGN OF NON-STRUCTURAL 1-SPECIFIC PRIMER PAIRS}

Four sets of previously published NS1-specific primers (Table 1) were chosen based on their complementarity to the full coding sequence of DENV2 NS1 gene (accession no: KX452042.1); the complementarity of the primer sequences and the template (DENV2 NS1 gene and the sizes of the PCR products were pre-determined using BLAST (Basic Local alignment Search Tool). The primers used were Yohan, Lee, Puspasari, Lemos and in-house primer pair. Besides, a pair of in-house NS1 primers was also synthesized. In the preliminary primer validation experiment, the pGEM-NS1 plasmid $(0.1 \mu \mathrm{g})$ (a courteous gift from Associate Professor Dr. Sharifah Syed Hassan, Monash University Sunway, Malaysia) was used as a template to confirm whether the previously published and in-house primers were able to amplify the DENV2 NS1 gene. A pair of control primers (DENV2NS1) was also included in the validation test.

\section{AMPLIFICATION OF THE DENV2 NS1 GENE}

The PCR was carried out as previously described (Tan et al. 2016; Yap et al. 2020) using the GoTaq HotStart DNA polymerase (Promega; Madison, Wisconsin, USA). The PCR reaction mixture $(50 \mathrm{~mL})$ consisted of $1 \mathrm{X}$ GoTaq

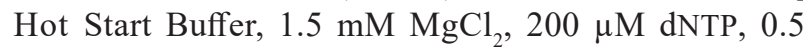
$\mu \mathrm{M}$ of each forward and reverse primer, $5 \mathrm{U}$ GoTaq HotStart DNA polymerase and $5 \mu \mathrm{L}(0.1 \mathrm{mg})$ of cDNA template. The PCR thermal cycles were as follows: initial denaturation at $94{ }^{\circ} \mathrm{C}$ for $2 \mathrm{~min}, 35$ cycles of denaturation at $94{ }^{\circ} \mathrm{C}$ for $1 \mathrm{~min}$, primer annealing at $55^{\circ} \mathrm{C}$ for $1 \mathrm{~min}$ and elongation at $72{ }^{\circ} \mathrm{C}$ for $1 \mathrm{~min}$, and final elongation at 72 ${ }^{\circ} \mathrm{C}$ for $10 \mathrm{~min}$. The amplification products were analyzed 
on a $1.5 \%(\mathrm{w} / \mathrm{v})$ agarose gel at $70 \mathrm{~V}$ for $45 \mathrm{~min}$. The molecular sizes of PCR products were compared to that of DNA markers (GeneRuler 100 bp Plus DNA Ladder, Thermofisher Scientific, US).

\section{RESULTS}

\section{VIABILITY OF DENV2-INFECTED VERO CELLS}

Figure 1 shows the percentage of cell death throughout the 14-day infection period. The pattern of cell death was proportional to the CPE observed (data not shown) throughout the incubation period. The percentage of cell death increased from day-3 to -14 p.i (Figure 1). The increase was especially drastic on day- 6 and -7 p.i. More than $90 \%$ of cell death was observed on day-12 to -14 p.i (Figure 1). Very mild CPE were first noted on day-2 p.i when cells started to form irregular cell morphology, cytoplasmic projection and cytoplasmic vacuolization. The nuclei looked more diffuse and the nuclear membranes began to disintegrate (data not shown). The CPE continued to exacerbate and the infected cells shrank and started to detach from the flask beyond day- 6 and -7 p.i (data not shown). They detached almost completely from the bottom of the flask on day-14 p.i. The dead cells aggregated and clumped together.

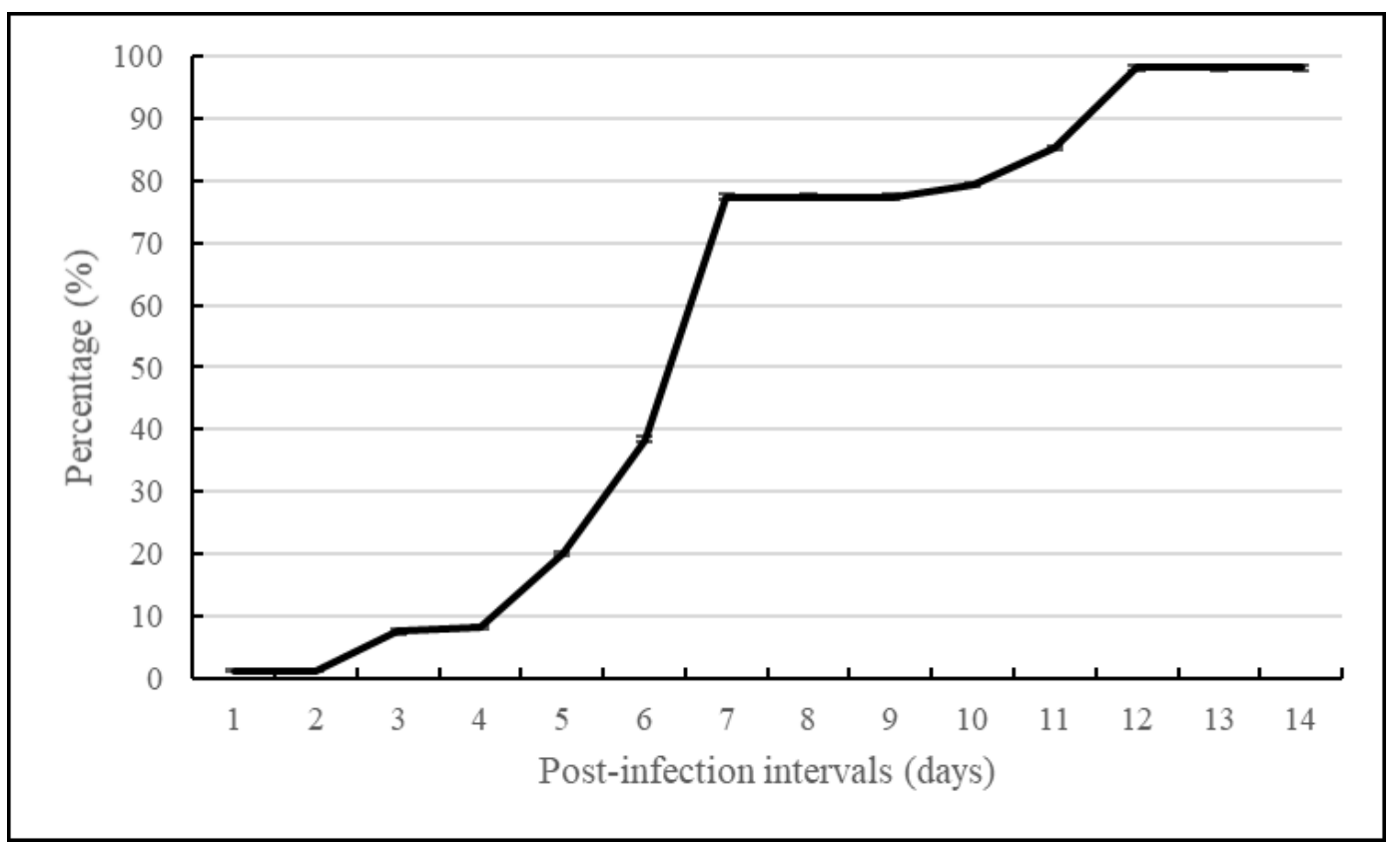

FIGURE 1. Percentage of cell death (min percentage + SD) of DENV2-infected Vero cells on day-1 to -14 p.i. There was a significant increase of cell death on day-7 ( 80\%). A nearly $100 \%$ cell death was recorded on days $12-14$ p.i

\section{VALIDATION OF THE NS1-SPECIFIC PRIMER PAIRS}

Validation of the NS1-specific primer pairs was done to ensure reliable results and prevent inconclusive findings. In this study, the sequences of a pair of inhouse and four sets of previously published NS1-specific primers were compared with the full-length sequence of DENV2 NS1 gene using the BLAST software and the findings were tabulated in Table 1. The sizes of the primers were 23-28 bp. Amongst the tested primers, the in-house primer pair showed the highest numbers of overlapping nucleotides in the forward (18 bp) and reverse (24 bp) primers with that of the NS1 gene. This was followed by the Lee and Lemos primer pairs consisting of 8 and 17 overlapping nucleotides in the forward and reverse primer sequences, respectively. Yohan and Puspasawi primer pairs, on the hand, carried only 7-9 overlapping nucleotides.

In order to corroborate the reliability and accuracy of these primers in amplifying the DENV2 NS1 gene from the infected samples, they were first used to amplify the NS1 gene from the pGEM-NS1 plasmid. The results (Figure 2) showed that only the in-house (Lane 
1) and Lemos (Lane 5) primer pairs were able to yield a positive amplification. The sizes of the amplicons were in accordance with the estimated molecular sizes (1056 and $1026 \mathrm{bp}$, respectively).

TABLE 1. Previously published and in-house primer pairs used in this study

\begin{tabular}{|c|c|c|c|}
\hline Source & Forward primer $\left(5^{\prime}-3{ }^{\prime}\right)$ & Reverse primer (5'-3') & $\begin{array}{l}\text { Molecular size of } \\
\text { amplicon (bp) }\end{array}$ \\
\hline $\begin{array}{l}\text { Yohan et al. } \\
\text { (2017) }\end{array}$ & TCGCGTTAACGCTAGCATGGATCTC & GTAACATCAGAGATTTTGAGACAC & 1323 \\
\hline $\begin{array}{l}\text { Lee et al. } \\
(2015)\end{array}$ & 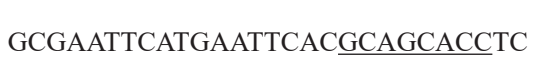 & GCCTCGAGCT $\underline{\text { GGCTGTGACCAAGGAGT }}$ & 1056 \\
\hline $\begin{array}{l}\text { Puspasari et } \\
\text { al. (2017) }\end{array}$ & GAATTCTCTGGTTGCGTCGTTAG & CTCGAGTTATTGTCCGTGACCAGC & 1000 \\
\hline $\begin{array}{l}\text { Lemos et al. } \\
\text { (2013) }\end{array}$ & GCGGATCCATGAATTCACGCAGCACCTC & GCCTCGAGCTGGCTGTGACCAAGGAGT & 1026 \\
\hline In-house & GAT AGT GGT TGC GTT GTG AGC TGG & GGC TGT GAC CAA AGA GTT GAC CAA & 1056 \\
\hline
\end{tabular}

Underlined sequences are overlapping sequences with that of the DENV2 NS1 gene

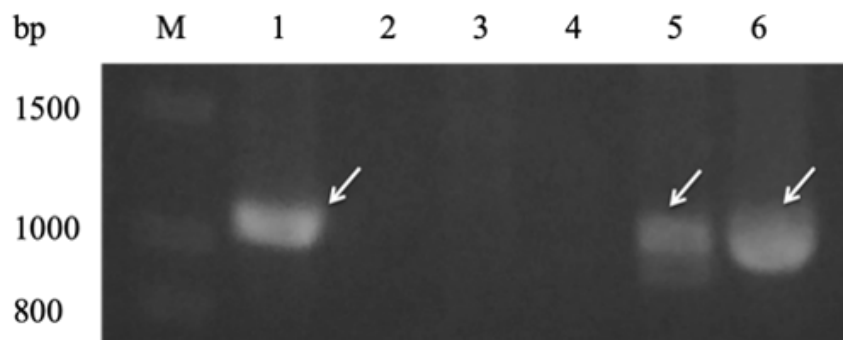

FIGURE 2. Validation of the previously published and in-house NS1 primers using the pGEM-NS1 plasmid. Lane M: molecular weight DNA markers (GeneRuler 100 bp DNA Ladder). The white arrows indicate the NS1 gene amplified using the, lanes 1: in-house primers (1056 bp); 2: Yohan primers (1323 bp); 3: Lee primers (1056 bp); 4: Puspasari primers (1000 bp); 5: Lemos primers (1026 bp); and 6: control primers (1056 bp; a generous gift by Assoc. Prof. Dr. Sharifah Syed Hassan). Amongst the primer pairs, only the in-house and Lemos primers were able to produce products with the expected sizes.

The control primers were included to rule out PCR reaction failure

\section{AMPLIFICATION OF NON-STRUCTURAL 1 GENE FROM DENGUE VIRUS TYPE 2-INFECTED VERO CELLS}

The in-house and Lemos primer pairs were subsequently used to amplify the DENV2 NS1 gene from DENV2- infected Vero cells. When using the in-house primer pair, the NS1 gene was successfully amplified from DENV2infected cells harvested on day-2, $-3,-5$ and -10 p.i as shown in Figure 3. As expected, the amplification produced 
a product of $1056 \mathrm{bp}$. There was unspecific amplification below the target band. However, the NS1 amplicon and the unspecific products could be easily distinguished based on their molecular sizes.
Unexpectedly, as for the Lemos primers (Figure 4), there was no gene amplification from the samples harvested on day-1 to day-14 p.i. On the control lane, there was a product amplified from the pGEM-NS1 plasmid using the Lemos primers (Figure 4, lane C).

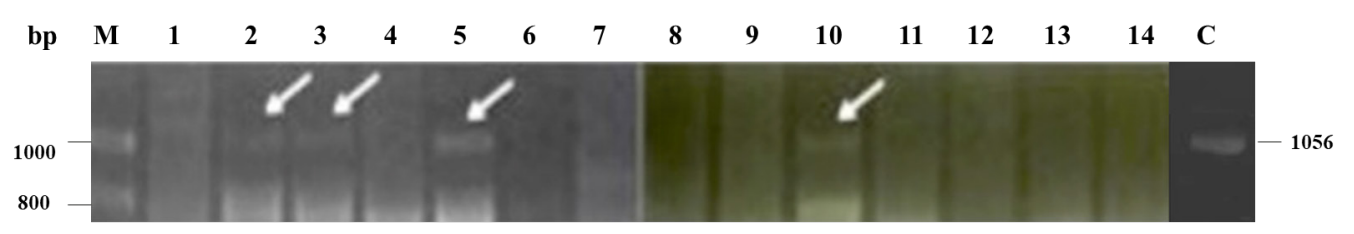

FIGURE 3. Amplification of the NS1 gene from DENV-2 infected Vero cells using the in-house primer pair. Lanes M: DNA markers (GeneRuler 100 bp DNA Ladder); 1-14: the PCR products (1056 bp) amplified from the DENV2-infected samples harvested on day-1 to -14 p.i.; C: amplicon (1056 bp) produced using pGEM-NS1 (control plasmid). The white arrows indicate the locations (lanes 2, 3, 5 and 10) of target amplicons. The control plasmid was included in the experiment to rule out PCR reaction failure

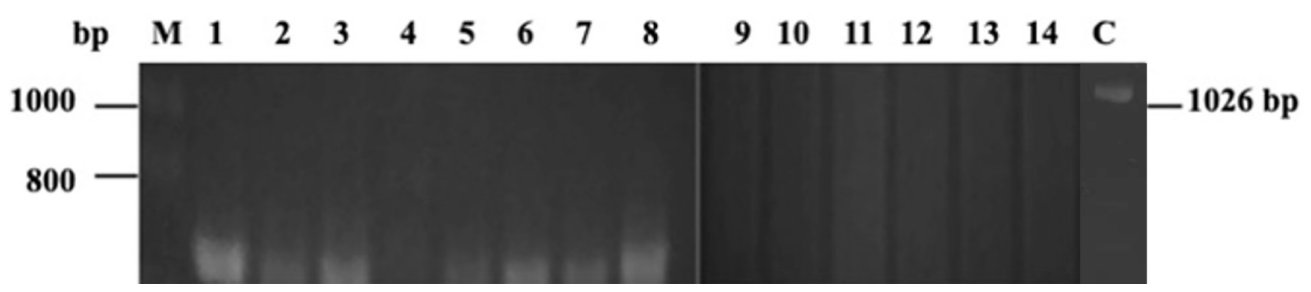

FIGURE 4. Amplification of the NS1 gene from DENV2-infected Vero cells using Lemos primer pair. Lanes M: DNA markers (GeneRuler 100 bp DNA Ladder); 1-14: amplification of the NS1 gene (1026 bp) from the infected samples on day1 to -14 p.i; and C: the NS1 gene (1026 bp) amplified from pGEM-NS1 plasmid. The target product was not observed on all the lanes except the control lane

\section{DISCUSSION}

An early detection of dengue impacts positively on the management of the disease especially during dengue outbreaks and in endemic areas (Jasamai et al. 2019). Diagnosing DENV infections using PCR-based molecular approaches are purportedly more advantageous than the conventional serological assays (Darwish et al. 2015) especially for the early detection of dengue prior to the onset of the disease symptoms (Alm et al. 2014). This is particularly useful for dengue epidemiological investigation and surveillance in highly endemic areas (Mfuh et al. 2019). As a result, it warrants a better disease treatment and management hence reduced morbidity and mortality among dengue patients (Muller \& Young 2013). The real-time PCR is one of the most frequently employed molecular methods in infectious disease diagnoses; however, its application requires specifically trained personnel for instrument handling and data interpretation (Mfuh et al. 2019). Hence, a simpler PCR-based method combining the agarose gel electrophoresis was employed in this study as a proof-of-concept to investigate the potential of the DENV2 NS1 gene as a biomarker for early detection of dengue. The DENV NS1 gene is highly expressed in infected cells that secrete the gene product abundantly into the circulation in the early course of dengue (Muller \& Young 2013).

The DENV2 infection was perpetuated in the Vero cell line over a period of 14 days in this study. This period signifies the intrinsic incubation period of dengue virus in human hosts prior to the onset of dengue symptoms 
(Chan \& Johansson 2012). As the virus replicates, it alters the normal biology of host cells, which in turn causes morphological aberrations. This was clearly demonstrated in this study when very mild CPE started to appear on day2 p.i. The infected cells formed irregular cellular outlines, vacuolization of cytoplasm and condensation of nuclei (Pilay et al. 2017). At the end of the viral replication, the virus progeny buds out and causes cell lysis and death (Tan et al. 2016). This is in line with the gradual increase of cell death observed on day-3 to $-14 \mathrm{p}$.i and also explains the cell detachment from the culture flasks at the end of the infection period. At this point of time, nearly $99 \%$ of cell death was documented.

In order to ensure a reliable, accurate diagnosis for dengue, it is imperative to pre-validate the primers used in the PCR-based molecular diagnostic approaches. This helps reduce the probability of unspecific amplification and false-negative results (Alm et al. 2014). Furthermore, inter-strain genotypic variations have been documented in circulating DENV strains isolated in Thailand (Tang et al. 2010). This underscores the importance of assuring primers used in PCR-based diagnoses are able to amplify the target DENV gene regardless of the newly emerging DENV strains, hence a more effective DENV detection and a sooner disease management and control (Mfuh et al. 2019). The validation of the primer pairs was done by amplifying the DENV2 NS1 gene from the pGEM-NS1 plasmid. The primers producing the desired amplicons were subsequently used in the amplification of the DENV2 NS1 gene from DENV2-infected samples.

The PCR using the in-house primer pair detected the DENV2 NS1 gene as early as day-2 p.i when the CPE and cell death were not even obvious. This finding implies the possibility of applying the DENV NS1 gene as an early biomarker for molecular dengue diagnosis. The early detection of DENV2 NS1 gene is mostly attributable to the expression of the viral NS1 gene as an important cofactor in the early stage of the virus replication (McBride 2009) in which its synthesis usually peaks within $72 \mathrm{~h}$ of DENV infections (Bessoff et al. 2008; Libraty et al. 2002). Alm et al. (2014) found that the DENV NS1 could retain in some dengue patients for up till nine days after the disease onset. This most likely explains the detection of DENV2 NS1 gene in infected cells within the first 5 days of infection in this study. As the virus replication progresses to the maturation stage, the expression of NS1 gene decreases (Suleman et al. 2016). Thereby, the NS1 gene was not detected in infected cells harvested on day -6 to -14 p.i except on day-10 p.i.

Although the Lemos primers were able to amplify the DENV2 NS1 gene from the pGEM-NS1 plasmid, they failed to amplify the target gene from the infected samples. It is speculated to be due to two major factors: the lower number of overlapping nucleotides in the Lemos primer pair with the template in comparison to that of the in-house primers, and the minute amount of viral mRNA present in the samples. Mismatches in primer sequences can reduce priming efficiency hence the higher the complementarity between primers and template, the higher PCR yield (Stadhouders et al. 2010). In the total RNA, the mRNA constituent is generally estimated around $0.03 \%$ (Rio et al. 2010). On that account, although the same amounts of the first-strand cDNA and pGEM-NS1 were employed in the PCR, the quantity of the viral mRNA in the infected samples was proportionally fewer hence the scarcity of the viral cDNA. This eventually minimizes the binding of Lemos primers to the viral cDNA and fails to amplify the NS1 gene. The complementarity of Yohan, Puspasari and Lee primer pairs with the DNA sequence of DENV2 NS1 gene was even lower, consequently, it deterred the primer-template annealing and abolished the PCR amplification reaction (Stadhouders et al. 2010; Yap et al. 2020).

Although the study outcomes support the potential of DENV NS1 gene as an early molecular marker in the PCR-based molecular diagnosis of dengue, several limitations have been noted in this study. Firstly, the verification of the findings with a more sensitive system such as real-time qPCR. The qPCR is able to detect minute copies of the target gene and also monitors the progression of the polymerase reaction; this is useful in authenticating the speculation bestowed upon the failure of Lemos primers to amplify the DENV2 NS1 gene from the infected samples (Alm et al. 2014). The qPCR, nevertheless, incurs a much higher application cost than the combination of conventional PCR and agarose gel electrophoresis (Alm et al. 2014). Secondly, in order to more precisely diagnose dengue, the PCR-based detection of the DENV NS1 gene can be further validated using clinical dengue samples and the results are compared with that of the currently used serological tests, which are commonly known to detect DENV-specific IgM after 5 days of the disease manifestation (Osorio et al. 2010; Shu et al. 2000). This justifies the applicability of the DENV NS1 gene as an early marker in PCR-based dengue diagnoses, which enables an early detection of dengue before the production of dengue-specific immunoglobulins. This, in turn, helps hasten the treatment, reduce the morbidity and disease complications among dengue-infected individuals.

In conclusion, this study suggests the potential of DENV NS1 gene as an early molecular marker for detecting DENV infections using PCR-based molecular 
approaches. This hopefully helps reduce the incidences of delayed treatments for dengue patients especially during dengue outbreaks and in endemic areas. On top of that, the early detection of dengue is also crucial since the clinical manifestations of dengue are usually unspecific and the definitive diagnosis of dengue relies greatly on the laboratory confirmation. Finally, the early detection of dengue based on the DENV NS1 gene using PCR-based molecular methods not only offers a better disease management but also helps in reducing the hospitalization cost and duration, mortality and morbidity.

\section{ACKNOWLEDGEMENTS}

This work was supported by the Fundamental Research Grant Scheme (FRGS), Ministry of Education, Malaysia (FRGS/1/2017/STG05/UKM/02/9).

\section{REFERENCES}

Ahmad, R., Suzilah, I., Wan, W.N., Topek, O., Mustafakamal, I. \& Lee, H.L. 2018. Factors determining dengue outbreak in Malaysia. PLoS ONE 13(2): e0193326.

Alm, E., Lesko, B., Lindegren, G., Ahlm, C., Söderholm, S., Falk, K.I. \& Lagerqvist, N. 2014. Universal single-probe RT-PCR assay for diagnosis of dengue virus infections. PLoS Neglected Tropical Diseases 8(12): e3416.

Ballow, M. 2002. Primary immunodeficiency disorders: Antibody deficiency. Journal of Allergy and Clinical Immunology 109(4): 581-591.

Bessoff, K., Delorey, M., Sun, W. \& Hunsperger, E. 2008. Comparison of two commercially available dengue virus (DENV) NS1 capture enzyme-linked immunosorbent assays using a single clinical sample for diagnosis of acute DENV infection. Clinical and Vaccine Immunology 15(10): 15131518.

Bhatt, S., Gething, P.W., Brady, O.J., Messina, J.P., Farlow, A.W., Moyes, C.L., Drake, J.M., Brownstein, J.S., Hoen, A.G., Sankoh, O., Myers, M.F., George, D.B., Jaenisch, T., Wint, G.R.W., Simmons, C.P., Scott, T.W., Farrar, J.J. \& Hay, S.I. 2013. The global distribution and burden of dengue. Nature 496(7446): 504-507.

Chambers, T.J., Hahn, C.S., Galler, R. \& Rice, C.M. 1990. Flavivirus genome organization, expression, and replication. Annual Review of Microbiology 44(1): 649-688.

Chan, M. \& Johansson, M.A. 2012. The incubation periods of dengue viruses. PLOS ONE 7(11): e50972.

Darwish, N.T., Alias, Y.B. \& Khor, S.M. 2015. An introduction to dengue-disease diagnostics. Trends in Analytical Chemistry 67: 45-55.

Guy, B., Briand, O., Lang, J., Saville, M. \& Jackson, N. 2015. Development of the Sanofi Pasteur tetravalent dengue vaccine: One more step forward. Vaccine 33(50): 7100-7111.
Guzman, M.G., Halstead, S.B., Artsob, H., Buchy, P., Farrar, J., Gubler, D.J., Hunsperger, E., Kroeger, A., Margolis, H.S., Martínez, E., Nathan, M.B., Pelegrino, J.L., Simmons, C., Yoksan, S. \& Peeling, R.W. 2010. Dengue: A continuing global threat. Nature Reviews Microbiology 8(12): S7-S16.

Hii, Y.L., Zaki, R.A., Aghamohammadi, N. \& Rocklöv, J. 2016. Research on climate and dengue in Malaysia: A systematic review. Current Environmental Health Reports 3(1): 81-90.

Jasamai, M., Yap, W.B., Sakulpanich, A. \& Jaleel, A. 2019. Current prevention and potential treatment options for dengue infection. Journal of Pharmacy and Pharmaceutical Sciences 22(1): 440-456.

Lee, J., Kim, H.Y., Chong, C.K. \& Song, H.O. 2015. Development and clinical evaluation of a highly accurate dengue NS1 rapid test: From the preparation of a soluble NS1 antigen to the construction of an RDT. Diagnostic Microbiology and Infectious Disease 82(2): 128-134.

Lemos, G., Guillén, I., Fernández, J.R., Díaz, T., Colarte, A.B. \& Fernández, C.M.E. 2013. Expression and purification of a full-length recombinant NS1 protein from a dengue 2 serotype viral isolate. Biotecnología Aplicada 30(3): 187193.

Libraty, D.H., Young, P.R., Pickering, D., Endy, T.P., Kalayanarooj, S., Green, S., Vaughn, D.W., Nisalak, A., Ennis, F.A. \& Rothman, A.L. 2002. High circulating levels of the dengue virus nonstructural protein NS1 early in dengue illness correlate with the development of dengue hemorrhagic fever. The Journal of Infectious Diseases 186(8): 1165-1168.

McBride, W.J. 2009. Evaluation of dengue NS1 test kits for the diagnosis of dengue fever. Diagnostic Microbiology and Infectious Disease 64(1): 31-36.

Mfuh, K.O., Achonduh-Atijegbe, O.A, Bekindaka, O.N., Esemu, L.F., Mbakop, C.D., Gandhi, K., Leke, R.G.F., Taylor, D.W. \& Nreurkar, V.R. 2019. A comparison of thickfim microscopy, rapid diagnostic test, and polymerase chain reaction for accurate diagnosis of Plasmodium falciparium malaria. Malaria Journal 18: 73.

Muller, D.A. \& Young, P.R. 2013. The flavivirus NS1 protein: Molecular and structural biology, immunology, role in pathogenesis and application as a diagnostic biomarker. Antiviral Research 98(2): 192-208.

Osorio, L., Ramirez, M., Bonelo, A., Villar, L.A. \& Parra, B. 2010. Comparison of the diagnostic accuracy of commercial NS1based diagnostic tests for early dengue infection. Virology Journal 7: 361

Packierisamy, P.R., Ng, C.W., Dahlui, M., Inbaraj, J., Balan, V.K., Halasa, Y.A. \& Shepard, D.S. 2015. Cost of dengue vector control activities in Malaysia. American Journal of Tropical Medicine and Hygiene 93(5): 1020-1027.

Pilay, K.P., Jasamai, M., Thayan, R., Santhanam, J., Hassan, S.S. \& Yap, W.B. 2017. Nucleoside analogs as potential antiviral agents for dengue virus infections. Medicinal Chemistry Research 26(7): 1382-1387. 
Puspasari, F., Putri, R.D., Aisyah, Damayanti, R.R., Yuwita, A., Alisjahbana, B., Handali, S., Ihsanawati \& Natalia, D. 2017. Construction and expression of a synthetic gene encoding nonstructural glycoprotein NS1 of dengue 2 virus in Pichia pastoris. Asian Pacific Journal of Tropical Biomedicine 7(8): 689-693.

Rio, D.C., Ares, M., Hannon, G.J. \& Nilsen, T.W. 2010. Preparation of cytoplasmic and nuclear RNA from tissue culture cells. Cold Spring Harbor Protocols 2010(6): pdbrot5441.

Rivetz, B., Siman-Tov, D., Ambal, E., Jaramillo, A.C., Ben-Zvi, A., Tartakovsky, B. \& Fish, F. 2009. New dengue antibody assay with unique differential detection of $\operatorname{IgG}$ and $\operatorname{IgM}$ antibodies. Clinical Biochemistry 42(3): 180-184.

Shu, P.Y., Chen, L.K., Chang, S.F., Yueh, Y.Y., Chow, L., Chien, L.J., Chin, C., Lin, T.H. \& Huang, J.H. 2000. Dengue NS1-specific antibody responses: Isotype distribution and serotyping in patients with dengue fever and dengue hemorrhagic fever. Journal of Medical Virology 62(2): 224-232.

Stadhouders, R., Pas, S.D., Anber, J., Voermans, J., Mes, T.H.M. \& Schutten, M. 2010. The effect of primer-template mismatches on the detection and quantification of nucleic acids using the 5' nuclease assay. Journal of Molecular Diagnostics 12(1): 103-117.

Suleman, M., Faryal, R., Alam, M.M., Sharif, S., Shaukat, S., Aamir, U.B., Khurshid, A., Angez, M., Umair, M., Sufian, M.M., Arshad, Y., Mujtaba, G. \& Zahoor Zaidai, S.S. 2016. NS1 antigen: A new beam of light in the early diagnosis of dengue infection. Asian Pacific Journal of Tropical Medicine 9(12): 1212-1214.

Tan, T.S., Hassan, S.S. \& Yap, W.B. 2016. Significant replication time-points of avian influenza A virus strain H5N1 in Madin-Darby Canine Kidney cells. Malaysian Journal Health Sciences 14(1): 17-21.

Tang, Y., Rodpradit, P., Chinnawirotpisan, P., Mammen Jr., M.P., Li, T., Lynch, J.A., Putnak, R. \& Zhang, C. 2010. Comparative analysis of full-Length genomic sequences of 10 dengue serotype 1 viruses associated with different genotypes, epidemics, and disease severity isolated in Thailand over 22 years. American Journal of Tropical Medicine and Hygiene 83(5): 1156-1165.

Tomlinson, S.M., Malmstrom, R.D. \& Watowich, S.J. 2009. New approaches to structure-based discovery of dengue protease inhibitors. Infectious Disorders-Drug Targets 9(3): 327-343.
Tuiskunen Bäck, A. \& Lundkvist, A.. 2013. Dengue viruses - An overview. Infection Ecology and Epidemiology 3(1): 19839.

Yap, W.B., Goh, K.C., Syed Hassan, S. \& Balasubramaniam V.RMT. 2020. Regulation of pro-apoptotic bax and trail gene expressions by H5N1 in Madin-Darby Canine Kidney (Mdck) cell line. Pakistan Veterinary Journal 40(4): 509513.

Yohan, B., Wardhani, P., Trimarsanto, H. \& Sasmono, R.T. 2017. Production of recombinant dengue non-structural 1 (NS1) proteins from clinical virus isolates. Protein Expression and Purification 129: 53-59.

Nur Azizah A Rahman, Fadhilah Moh Djamil \& Wei Boon Yap* Biomedical Science Programme

Faculty of Health Sciences

Universiti Kebangsaan Malaysia

Jalan Raja Muda Abdul Aziz

50300 Kuala Lumpur, Federal Territory

Malaysia

Nur Azizah A Rahman \& Wei Boon Yap*

Center of Toxicology and Health Risk Studies

Faculty of Health Sciences

Universiti Kebangsaan Malaysia

Jalan Raja Muda Abdul Aziz

50300 Kuala Lumpur, Federal Territory

Malaysia

Vinod RMT Balasubramaniam \& Sharifah Syed Hassan Jeffrey Cheah School of Medicine \& Health Sciences

Monash University Malaysia

Jalan Lagoon Selatan

46150 Bandar Sunway, Selangor Darul Ehsan

Malaysia

Fadhilah Moh Djamil

Microbiology Unit, Department of Pathology

Tuanku Ja'afar Hospital

Jalan Rasah, Bukit Rasah

70300 Seremban, Negeri Sembilan Darul Khusus

Malaysia

*Corresponding author; email: yapweiboon@ukm.edu.my

Received: 26 October 2020

Accepted: 19 February 2021 